\title{
Kiai Leadership Concept in The Scope of Pesantren Organizational Culture
}

\author{
Received: 08-11-2021 \\ Revised: 28-12-2021 \\ Accepted: 20-01-2022
}

Siti Aisyah ${ }^{1}$, Munaya Ulil Ilmi ${ }^{2}$, Muhammad Amirudin Rosyid', Eni Wulandari ${ }^{4}$, Fandi Akhmad 5

Faculty of Islamic Religion, Ahmad Dahlan University, Indonesia1, 2, 3, 4,5

Email: $\underline{\text { siti1800031227@webmail.uad.ac.ic }}{ }^{1}$,

\begin{tabular}{l}
\hline \\
\hline Keywords: \\
\hline Organizational \\
culture, \\
Leadership, Kiai, \\
Islamic Boarding \\
School.
\end{tabular}

Kata kunci:

Budaya Organisasi, Kepemimpinan, Kiai, Pesantren

\begin{abstract}
Leadership in the organizational culture of pesantren (Islamic Boarding School) has characteristics following the pesantren culture and prevailing religious values. As the pesantren leader, Kiai leads in a charismatic style that is full of authority and responsibility. This study aims to review the leadership of the Kiai in the organizational culture of the pesantren. It was assessed by using a library research model. The results showed that the administration of the Kiai had a significant influence on the achievement of the goals of the pesantren. Leadership values are expected to be passed down from generation to generation to future leaders. The leadership of a Kiai and the culture of the Islamic boarding school are two things that influence each other. The Kiai's task as the pesantren leader is to form a personal commitment to the pesantren as an Islamic educational institution. A Kiai must maintain the culture or culture of the Islamic boarding school that has been preserved for centuries.
\end{abstract}




\section{Tafkir: Interdisciplinary Journal of Islamic Education}

\section{INTRODUCTION}

Discussion of leadership is an important and exciting study to explore. Every human being on earth is a leader. Every leader will be held accountable for their leadership. Man as a leader is at least capable of leading himself, leading to a straight path and a purposeful life. ${ }^{1}$

Leadership comes from the word lead, which contains two main things: the subject in the form of a leader and the led object. Authority means directing, organizing, guiding, building, influencing, or showing. ${ }^{2}$ Leadership is the ability of a person who aims to influence others to achieve common goals. ${ }^{3}$ Speaking of the understanding of leadership, the figures vary in interpreting it-leadership as a force to exert struggle or activity towards success. ${ }^{4}$ Everyone can lead, but many people do not realize it.

Leadership as a person's behavior to lead can happen anywhere and anytime. The leadership process occurs in households, schools, companies, mosques, and various community organizations. No leader is perfect. ${ }^{5}$ There is no patent theory that a leader uses to lead an institution. A'yuni and Hijrawan argue that the ideal leadership is the one that can show according to the circumstances, circumstances, and conditions of the institution he leads. ${ }^{6}$

Pesantren is the forerunner of Islamic education in Indonesia. The beginning of the emergence of pesantren is estimated to date back 300-400 years and reach almost all levels of the Indonesian Muslim community, especially in Java. ${ }^{7}$ Pesantren is defined as a form of traditional education in Indonesia whose history had begun

1 Raihani, 'Report on Multicultural Education in Pesantren', Compare: A Journal of Comparative and International Education 42, no. 4 (1 July 2012): 585-605, https://doi.org/10.1080/03057925.2012.672255.

2Muhammad Ichsan Thaib, 'Kepemimpinan Pendidikan Dalam Islam', Jurnal Intelektualita 4, no. 66-95 (2016).

${ }^{3}$ Asep Solikin, H.M Fatchurahman, and Supardi, 'Pemimpin Yang Melayani Dalam Membangun Bangsa Yang Mandiri', Anterior Jurnal 16, no. 2 (2017): 90-103.

4Jamaluddin Idris, Manajerial Dan Manajemen (Bandung: Citapustaka Media Perintis, 2013).

${ }^{5}$ Siti Qurrotul A'yuni and Radia Hijrawan, 'Analisis Kritis Kepemimpinan Pendidikan Islam Berdasarkan Syarat Dan Ciri-Ciri Kepemimpinan Yang Ideal', Al-Fahmi: Jurnal Manajemen Pendidikan Islam 2, no. 2 (2020).

6 Yusuf Hanafi et al., 'The New Identity of Indonesian Islamic Boarding Schools in the "New Normal": The Education Leadership Response to COVID-19', Heliyon 7, no. 3 (1 March 2021): e06549, https://doi.org/10.1016/j.heliyon.2021.e06549.

7Imam Syafe'i, 'Pondok Pesantren: Lembaga Pendidikan Pembentukan Karakter', Al-Tadzkiyyah: Jurnal Pendidikan Islam 8, no. 1 (2017): 61-82. 


\section{Siti Aisyah et al}

hundreds of years before Indonesia was declared independent. 8 The word "pesantren" contains the meaning as a place for students or students, while "santri" is thought to come from Sanskrit, which means "literate," or from the Javanese "cantrik" which means people who follow their teachers everywhere they go. From this understanding, we know that pesantren now act has three elements: santri, Kiai, and dormitory $\cdot 9$

A Kiai leads leadership in pesantren. Based on research, Kiai plays a role as an imam in ubudiyah and religious rituals and contributes to the community in solving cases or difficulties.10 Kiai leadership in pesantren is called "art," utilizing power (energy, funds, and means) to mobilize pesantren citizens to do something following the will of Kiai as a form of effort in realizing the purpose of pesantren. ${ }^{11}$

Culture has a decisive role in creating the success of an institution. The culture can give meaning to the achievement of an institution's goals. ${ }^{12}$ Similarly, in pesantren, when the culture of pesantren is mature, then all the components in it will be united in the same tradition or habit. ${ }^{13}$ Through the leadership, Kiai is very influential in forming pesantren culture. The culture of an institution characterizes one institution to distinguish it from another institution. Cultural differences and characteristics certainly affect the model of leadership that is run. Based on the description above, researchers are interested in studying the leadership that occurs in the cultural scope of pesantren organizations. ${ }^{14}$

8 Abubakar Yakubu, 'Pondok, Tsangaya, and Old Age Spiritual Wellbeing', Tafkir: Interdisciplinary Journal of Islamic Education 2, no. 2 (25 July 2021): 122-38, https://doi.org/10.31538/tijie.v2i2.44.

9 Herman Herman, 'Sejarah Pesantren Di Indonesia', Al-TA'DIB: Jurnal Kajian Ilmu Kependidikan 6, no. 2 (2013): 145-58.

10 Muslichan Noor, 'Gaya Kepemimpinan Kyai', Jurnal Kependidikan 7, no. 1 (31 May 2019): 141-56, https://doi.org/10.24090/jk.v7i1.2958.

11Mardiyah, Keoemimpinan Kyai Dalam Memelihara Budaya Organisasi (Malang: Aditya Media Publishing, 2012).

12Munaya Ulil Ilmi, 'Penerapan Disiplin Melalui Budaya Sekolah Pada Siswa Kelas IX MTs Ponpes Islam Al Iman Muntilan', Instructional Development Journal 3, no. 3 (2020): 203-11.

${ }^{13}$ Fitri Rayani Siregar, 'Nilai-Nilai Sekolah Dalam Pembinaan Aktivasi Keagamaan Siswa SD IT Bunayya Padangsidimpuan', Jurnal Pusat Gender Dan Anak 1, no. 1 (2017).

14 Nur Khusniyah Indrawati, 'Management by Inspiration: Implementation of Transformational Leadership on Business at Pondok Pesantren*) Sunan Drajat', Procedia - Social and Behavioral Sciences, The 5th Indonesia International Conference on Innovation, Entrepreneurship, and Small Business (IICIES 2013), 115 (21 February 2014): 79-90, https://doi.org/10.1016/j.sbspro.2014.02.417. 


\section{RESULTS OF RESEARCH AND DISCUSSION}

\section{Leadership in Pesantren}

A leader manages an organization that can direct all organizational activities to achieve specific goals. ${ }^{16}$ At the same time, leadership is a process of direction and influences activities associated with duty from the group members. ${ }^{17}$

Pondok pesantren considered the oldest Islam educational institution in Indonesia, can be seen in material, methods, education system, and leadership style. Pondok pesantren itself is divided into two types: traditional boarding school with a character leadership system wherein its teaching still uses a non-classical system where the main focus is learning the Quran and Arabic to deepen understanding of the books of fiqh, date, hadith, and others. This is in contrast to modern boarding schools that adhere to the foundation system, formal schools in general whose teaching uses classical methods to learn general sciences while studying the Quran. ${ }^{18}$

Islam views the leadership position very strategically because, with a good leader, it will be realized the community based on Baldatun Thoyyibatun Wa Rabbun Ghafûr that the people always apply the principles of Islam. Likewise, the boarding school must have a leader who manages leadership in the boarding school to run well. ${ }^{19}$

Leadership in boarding schools turns out to have several styles, namely: first, transformational leaders. This leadership style leads to the future, passionate and open thinking and focused on the future so that this leadership can improve the performance of its subordinates in increasing output and providing oversight over the performance of its associates to bring change, not to themselves but the people in the organization can achieve a high level of performance. ${ }^{20}$ Second, charismatic leaders. This style can influence one to build an idea in a creative, authoritative way, have tremendous energy, appeal, and a carrier to influence others as honestly as ideological goals that connect the group's mission to deeply rooted values, ideals, and

16Mahfud Ifendi, 'Pesantren Dan Kepemimpinan Kiai: Studi Kasus Di Pondok Pesantren Mambaus Sholihin Gresik (1980-2020)', Mudir: Jurnal Manajemen Pendidikan 2, no. 2 (2020): 13-30.

17Bedjo Siswanto, Pengantar Manajemen (Bumi Aksara, 2021).

${ }^{18}$ ELKA DESTY Ariandy, 'Pondok Pesantren Di Yogyakrta Yang Didasarkan Pada Kaidah Islam Mengenai Kemasyarakatan' (UAJY, 2009).

${ }^{19}$ Nor Fithriah, 'Kepemimpinan Pendidikan Pesantren (Studi Kewibawaan Pada Pondok Pesantren Salafiyah, Modern, Dan Kombinasi)', Al Qalam: Jurnal Ilmiah Keagamaan Dan Kemasyarakatan, 2018, 13-30.

20A Hosaini, 'Kepemimpinan Dan Budaya Organisasi Di Pesantren', Likhitaprajna 17, no. 2 (2015): 86-95.

43| Vol. 3, No.1, January 2022 


\section{Siti Aisyah et al}

aspirations shared by followers. ${ }^{21}$ In addition, charismatic leaders use the advantages of their personality to influence thoughts, feelings, and behavior of others because of their extraordinary character and authority. ${ }^{22}$ The third is the servant leader. This leadership style is unique because the leader prioritizes all the needs and expectations of others above his interests - thus establishing a style of democratic leadership. After all, decision-making involves the whole team. ${ }^{23}$ Fourth, the spiritual leader. This leadership style can change how a person sees and acts. In contrast, a spiritual leadership style is proactive in taking over a person's situation, actions, or behavior -fifth, authentic leadership. Authentic leadership can merge with previous leadership styles or other forms of positive leadership, meaning they prioritize serving people under their supervision rather than seeking only prestige, money, and power. ${ }^{24}$

It ordered itself needed a leader who can direct all activities to run well, namely Kiai leadership. According to Kasful Anwar, effective leadership is more inclined to the charismatic style, where charismatic leadership demonstrates the authority by a high sense of responsibility to generate trust and a proactive attitude towards his subordinates. ${ }^{25}$ The charismatic leadership of the Kiai arises by the reason that the community around pesantren and santri considers that Kiai is an extension of God's hand to convey His teachings. This belief leads to a $\operatorname{taklid}^{27}$ attitude (obeying without knowing the science). This almost becomes a tradition in the lives of santri and worshipers.

21 Triyuni Soemartono, 'Reconstruction of Education Policy in Jembrana Bali, Best Practices of Creative and Innovative Leadership Using Soft Systems Methodology Based Action Research', Procedia - Social and Behavioral Sciences, The 5th Indonesia International Conference on Innovation, Entrepreneurship, and Small Business (IICIES 2013), 115 (21 February 2014): 269-82, https:/ / doi.org/10.1016/j.sbspro.2014.02.435.

${ }_{22}^{2}$ HILA Qori, 'Kepemimpinan Karismatik versus Kepemimpinan Transformasional', Jurnal Analisa 1, no. 2 (2013): 70-77.

23 Wenbin Liu and Bernard Gumah, 'Leadership Style and Self-Efficacy: The Influences of Feedback', Journal of Psychology in Africa 30, no. 4 (3 August 2020): 289-94, https://doi.org/10.1080/14330237.2020.1777033.

24 Martina Kotzé and Petrus Nel, 'Personal Factor Effects on Authentic Leadership', Journal of Psychology in Africa 27, no. 1 (27 February 2017): 47-53, https://doi.org/10.1080/14330237.2016.1268291.

25 Zainal Arifin, 'Authority of Spiritual Leadership at Pesantren Temboro Based on Jamaah Tabligh Ideology', Jurnal Pendidikan Islam 6, no. 2 (27 December 2017): 265-92, https:// doi.org/10.14421/jpi.2017.62.265-292.

27Kasful Anwar, 'Kepemimpinan Kiai Pesantren: Studi Terhadap Pondok Pesantren Di Kota Jambi', Kontekstualita: Jurnal Penelitian Sosial Keagamaan 25, no. 2 (2010). 


\section{Tafkir: Interdisciplinary Journal of Islamic Education}

According to Wahjosumidjo, "the charisma of Kiai leadership is related to the breadth of mastery of religious science studies in Kiai and consistency of practice of spiritual science in daily life Kiai, in other words, that charisma can be similar to power Kiai, then charismatic leadership Kiai can also be examined with the concept of sources of authority.28"

But according to Ahamd Hosain, Kiai leadership in leading pesantren tends to be more in an authentic style, and this is because authentic leadership can merge the previous leadership style or other forms of positive leadership, meaning they prioritize serving people under his leadership rather than prestige, money, and power. Kiai is the leader of pesantren, which is synonymous with understanding religious science, upholds spirituality, protects and serves santri, commits to the people's future, and still has a strong charisma. Because the recommended leader is an authentic leader that is honest and good to individuals and groups. ${ }^{29}$ Leadership has five main characteristics: first, providing answers for people who seek good and strong leadership..$^{30}$ Second, it is definite and includes much information about how leaders learn to be authentic. Third, have an explicit moral dimension (to the point)so that people can easily understand it. Fourth, the process is limited by the leader over time. Fifth, this leadership can be measured by theory-based instruments and accounted for. ${ }^{31}$

Kiai's leadership in pesantren to realize and develop the progress of pesantren huts is not for personal but for the benefit of santri and its worshipers. Pesantren became a place to spread religious knowledge to eradicate ignorance and give birth to insightful santri-santri in the future, where santri-santri got a proper education. ${ }^{32}$

${ }^{28}$ Chusnul Muali et al., 'The Role of Sufistic-Based Kiai Leadership in Developing the Character of Santri in the Pesantren', AL-ISHLAH: Jurnal Pendidikan 13, no. 3 (2 November 2021): 1705-14, https:/ / doi.org/10.35445/alishlah.v13i3.1012; Sverre Spoelstra, 'The Paradigm of the Charismatic Leader', Leadership 15, no. 6 (1 December 2019): 744-49, https:// doi.org/10.1177/1742715019853946.

29 Manjurul Hossain, 'Political Activities of Sheikh Mujibur Rahman as A Charismatic Leader', London Journal of Research in Humanities and Social Sciences, 22 August 2019, https://research.journalspress.com/index.php/socialscience/article/view/463.

30Aniek Rahmaniah, 'Pengembangan Pembelajaran Ilmu Pengetahuan Sosial Pada Pendidikan Dasar', Madrasah 5, no. 1 (2012): 103-22.

31 Sarfaraz Javed, Azam Malik, and Mutaz Minwer Hala Alharbi, 'The Relevance of Leadership Styles and Islamic Work Ethics in Managerial Effectiveness', PSU Research Review 4, no. 3 (1 January 2020): 189207, https:/ / doi.org/10.1108/PRR-03-2019-0007.

${ }^{32}$ M Makki, 'Model Kepemimpinan Tuan Guru Di Pondok Pesantren Kabupaten Lombok Timur NTB', Jurnal Manajemen Dan Budaya 1, no. 2 (2021): 65-84. 


\section{Siti Aisyah et al}

Each boarding school leader has their policy sometimes not following the quality standards of madrasah, especially the middle of content, process, and educators and education personnel. Therefore, it takes cooperation between Kiai as leaders, educators, and pesantren citizens to optimize the potential and activities of pesantren more efficiently and effectively in carrying out their policies to achieve existing goals. ${ }^{33}$

\section{Organizational Culture in Pesantren}

Pondok pesantren is a religious education institution for students who study spiritual science or "ngaji" Islamic sacred science. Pesantren hut is synonymous with Islamic meaning and defines authenticity (indigenous) Indonesia as an institution. ${ }^{34}$ The development of boarding schools in Indonesia can be divided into three types. First, traditionally, this Pesantren retained its original form only by teaching the books (yellow) written by the classics using Arabic. The learning model can be small or semi-yearly, and the level of education is not time-dependent. And after the completion of a particular book, students can proceed to the next level by studying the book. This approach follows the principles of the modern process known as the complete learning system. This allows students to focus more on one area of science. Second, Islamic boarding school modern, this boarding school uses madrasah (MI, MT, MA) and school (elementary, junior high, high school, vocational school), but with a modern approach through formal events in classical format and organizing educational activities. Access (class) in program units is based on units of time. There are no teachings in the classical Islamic books. Although the student studied Arabic, the ability was not focused on understanding Arabic in classical texts. In modern boarding schools, santri must master Arabic and English. Third, combined boarding school integrates a complete curriculum with a combination of traditional and contemporary contents to provide a comprehensive education. ${ }^{35}$

Efforts to develop the culture of pesantren organizations began when it elected new members. The leader of the boarding school certainly does not want to take risks

\footnotetext{
${ }^{33}$ Kevin W. Fogg, 'Reinforcing Charisma in the Bureaucratisation of Indonesian Islamic Organisations', Journal of Current Southeast Asian Affairs 37, no. 1 (1 April 2018): 117-40, https://doi.org/10.1177/186810341803700105.

${ }^{34}$ Madjid Nurcholish, Bilik-Bilik Pesantren Sebuah Potret Perjalanan (Jakarta: Paramadina, 1997).

35 Aya Mamlu'ah, 'Pengembangan Budaya Organisasi Pesantren Dalam Manajemen Pendidikan Islam', Al Ulya: Jurnal Pendidikan Islam 2, no. 1 (22 February 2017): 28-40, https:/ / doi.org/10.36840/ulya.v2i1.71.
}

46| Vol. 3, No.1, January 2022 


\section{Tafkir: Interdisciplinary Journal of Islamic Education}

in choosing new members whose background is not known. ${ }^{37}$ Usually, the pesantren leader does not want to select members who are considered not suitable for the culture and conditions of the boarding school. This selection process aims to identify the level of knowledge, skills, and abilities of new members of the organization and to know the values of individuals, personalities, and individual backgrounds. ${ }^{38}$

As the leader of the pesantren hut, Kiai has an essential role in shaping organizational culture in pesantren. This is done to form a character of the institution that is different from other institutions. The character of the institution is used as the identity of an organization, so Kiai as the leader of the institution is required to maintain the organizational culture and brand that has been built. In other words, corporate culture can be interpreted as an agreement of the process of forming institutional excellence. ${ }^{39}$

Implementing the values, objectives, vision, and mission of pesantren, leadership always motivates all mentors, foundation chairs, general chairpersons, and boarding school administrators to create a supportive environment. This is usually done at the annual leadership meeting. Furthermore, the implementation of the values, goals, vision, and cultural mission of pesantren organizations is required of all persons in charge of each level of the structure. The training of the organization of boarding schools was organized and regional organization forums. The cottage supervisor usually becomes a builder and advisor to the organization at the respective regions. Their involvement in the organization marhalah is related to its function as a companion and leader marhalah. It can be concluded that the process of the leadership of pesantren huts in fostering the culture of pesantren organization has begun to be instilled not only in the board but also in the santri-santri through boarding school activities. Regional organizations and students also have complex organizations that

\footnotetext{
37 Saipul Hamdi, Paul J. Carnegie, and Bianca J. Smith, 'The Recovery of a Non-Violent Identity for an Islamist Pesantren in an Age of Terror', Australian Journal of International Affairs 69, no. 6 (2 November 2015): 692-710, https:/ / doi.org/10.1080/10357718.2015.1058339.

38 Amanah Nurish, 'Women's Same-Sex Relations in Indonesian Pesantren', Gender, Technology and Development 14, no. 2 (1 January 2010): 267-77, https://doi.org/10.1177/097185241001400207.

${ }^{39}$ Mastuhu, Dinamika Sistem Pendidikan Pesantren Suatu Kajian Tentang Unsur Dan Nilai Sistem Pendidikan Pesantren (Jakarta: INIS, 1994).
} 


\section{Siti Aisyah et al}

usually consist of one level or one class. Every organization has regular activities carried out every week called jamiyah..$^{40}$

The original plan for transformational leadership was formulated by Burns from descriptive research on political leaders. Change leaders strive to transform vision into a common goal to make dreams a reality. The change process can be seen through leadership behaviors such as idealized influence, intellectual stimulation, attributed charisma, individualized consideration, and inspirational motivation. Meanwhile, the concept of organizational culture is understood in three madhhabs, namely: 1) Madzhab Ideational School: This madhab views an organization's culture more than what is imbued practiced together and understood by members of a community or community. 2) Madzhab Adaptationist School: In this madhab, look at the culture of what can be well researched from the organizational structure, such as the makeup in an organization. 3) Madzhab Realist School: In this madhab, organizational culture is something complex that cannot be understood only from the behavior of its people but also the source of the behavior. ${ }^{41}$

A long history is one part of the forming factor and the embodiment of pesantren culture. Hodge and Anthony argue that organizational culture is depicted in sagas, myths, and legends. Long-established organizations have saga organizations, a shared understanding based on the history of corporate success that provides a normative foundation for organization members both out and into. The organization is one of the most valuable resources because it was formed many years. ${ }^{42}$

Pondok pesantren has been considered a form of educational institution that has a good advantage in scientific tradition and is regarded as one of the great cultures (great practice), although on the side of spread and internalization morals. On the other hand, pesantren is also an education that can show the role of civil society empowerment and transformation..$^{43}$ Every organization has ways, rules, and habits in

${ }^{40}$ Ah. Choiron, 'Budaya Organisasi Pesantren Dalam Membentuk Santri Putri Yang Peduli Konservasi Lingkungan', Jurnal Palastren 10, no. 2 (2017).

${ }^{41}$ Mardiyah, Keoemimpinan Kyai Dalam Memelihara Budaya Organisasi.

${ }^{42}$ H.M. Yunus Abu Bakar, 'Konsep Pemikiran Pendidikan K.H. Imam Zarkasyi Dan Implementasinya Pada Pondok Pesantren Alumni' (UIN Sunan Kalijaga, 2007).

43 Ismail Suardi Wekke and Sanusi Hamid, 'Technology on Language Teaching and Learning: A Research on Indonesian Pesantren', Procedia - Social and Behavioral Sciences, 2nd World Conference on Educational Technology Research, 83 (4 July 2013): 585-89, https://doi.org/10.1016/j.sbspro.2013.06.111.

48 | Vol. 3, No.1, January 2022 


\section{Tafkir: Interdisciplinary Journal of Islamic Education}

acquiring the vision and mission of the organization, including the way it lives with each other or society and the way individuals overcome the problems faced by an organization. Life is based on a creed based on attitude, based on man's relationship with his environment. ${ }^{44}$

In developing pesantren, a transparent organization is needed with a simple form but explains the objectives, essential obligations, and functional elements. These habits are to ensure flexibility that will allow for development or change. In theory, the organization of pesantren can be complex or straightforward. In the method of socialization of organizational culture, some relationships occur between members of the organization. Relationships that occur in an organization are referred to as corporate communication. Globally, organizational communication can be distinguished from official and unofficial communication. Official communication is all determined by the structure that has been planned and cannot be denied by an organization. When a message flows through an official path defined by the authorized level of the organization or the function of the work, it is within an official line of communication. ${ }^{45}$

Kiai is a pesantren leader who can apply and communicate the vision correctly and adequately to enable the successful role of leaders in forming a commitment to pesantren values and organizational culture. The culture of organization and leadership influence each other. Executive culture influences leadership and leadership influences corporate culture. Organizational culture and leadership influence job satisfaction and personnel commitment. ${ }^{46}$

As a leader in pesantren, Kiai has a significant influence in shaping the culture of pesantren organizations more supportive. Kiai has a high role in controlling pesantren, so Kiai's leadership in pesantren is expected to be the best solution in shaping organizational culture in pesantren more fun and comfortable. In addition, Kiai as the

${ }^{44}$ Sri Rokhlinasari, 'Budaya Organisasi Pesantren Dalam Pengembangan Wirausaha Santri Di Wirausaha Lan Taburo Kota Cirebon', Jurnal Holistik 15, no. 2 (2014).

${ }^{45}$ Dede Husni Mubarok and Malik Fatoni, 'Mempertahankan Budaya Organisasi Melalui Best Practices Pendidikan Spiritual Leadership Pada Pondok Pesantren', Jurnal Geneologi: Jurnal Pendidikan Agama Islam 5, no. 1 (2018).

46 Jarjani Usman, Syabuddin Syabuddin, and Faishal Zakaria, 'Teungku Identity Development: The Role of Dayah Community of Practice', SAGE Open 11, no. 3 (1 July 2021): 21582440211031532, https://doi.org/10.1177/21582440211031532.

49| Vol. 3, No.1, January 2022 


\section{Siti Aisyah et al}

leader of pesantren, also has the task to condition all the parts in the pesantren can be controlled and create commitment in personnel in the organization and fun work. The realization of commitment to the organization will result in the organization's progress. Therefore, it takes positive Kiai leadership. ${ }^{47}$

The leader and founder of the boarding school also has an essential role in shaping the organizational culture in pesantren, which aims to build a character that can distinguish it from other institutions. ${ }^{48}$ The essence of an institution is a characteristic of the organization. It can be interpreted as a meaning of the process of forming institutional excellence that can be indicated by two things, namely the clarity of the education management system of pesantren hut and the growth of scientific traditions. ${ }^{49}$

Thus, Kiai's job as a pesantren leader is to form a personnel commitment to pesantren as an Islamic educational institution. As the leader of pesantren, Kiai can understand, implement and energize in a committed manner to the values of pesantren to serve as the basis for pesantren behavior in achieving the desired goals of pesantren so that it will enable the implementation of a successful leadership role in building organizational culture in pesantren. 50

\section{Pesantren Leadership and Culture Relations}

A good organization, growing, and developing will provide human resources to optimally carry out its functions, especially when facing the dynamics of environmental changes. This proves that the technical, theoretical, conceptual, and moral abilities in organizations at all levels of work are highly expected. Leadership will serve and have moral teachings that are very important in an organization. According to Yasin, leadership is described as completing work through a person or group. The performance of managers depends on their ability to lead. This means that

47 Yanwar Pribadi, 'The Klebun, the Kiai and the Blater: Notes from Western Madura, Indonesia', South East Asia Research 23, no. 3 (1 September 2015): 303-17, https://doi.org/10.5367/sear.2015.0267.

48 Imron Arifin et al., 'Islamic Crash Course as a Leadership Strategy of School Principals in Strengthening School Organizational Culture', SAGE Open 8, no. 3 (1 July 2018): 2158244018799849, https://doi.org/10.1177/2158244018799849.

${ }^{49}$ Muhammad Najih, 'Sosialisasi Budaya Organisasi Di Pondok Pesantren Muhammadiyyah: Studi Kasus Sosialisasi Budaya Organisasi Di Pendidikan Ulama Tarjih Muhammadiyah', Jurnal Channel 3, no. 2 (2015).

50 Siti Raba'ah Hamzah et al., 'Impact of Islamic Values on the Leadership Style of Muslim Women Academics in Malaysia', Advances in Developing Human Resources 18, no. 2 (1 May 2016): 187-203, https://doi.org/10.1177/1523422316641402. 


\section{Tafkir: Interdisciplinary Journal of Islamic Education}

leaders can influence people or groups to achieve something they want and set organizational goals. ${ }^{51}$

A leader is an essential element in carrying out an organized life concerning the conditions of his subordinates. As a result, when making decisions, the leader must involve his subordinates' participation. The decision in involving assistants was an effort to accommodate everyone constructively to achieve the organization's goals. This is because it can be considered that when in organizations, there is a culture that has been formed in the routine of organizational life. ${ }^{52}$ Placement of leadership behavior according to corporate culture is essential to direct the attitude and direction of subordinate behavior for the completion of tasks oriented to organizational goals. Organizational life also requires the fulfillment of individual needs comprehensively to work optimally. ${ }^{53}$

Therefore, the motivation that tends to be constructive and arousing for subordinates is expected by a leader to be a form of direction to individuals to be more invited to relate to the achievement of organizational goals effectively. Of course, every leader cannot use one leadership style alone or use another term as a situational condition to set a benchmark to take every decision. Situational participatory leadership allows leaders and subordinates to interact simultaneously through support and direction mechanisms. These conditions become the basis of participatory leadership with the national situation approach. ${ }^{54}$

The correlation between leadership and organizational culture is the social dimension of the organization that has recently been an exciting study. Leadership research emphasizes distinctive approaches, attitudes, power, impact, and situational that are still one-way. The perspective of organizations becoming social systems already provides a cultural dimension as an essential part that influences leadership effectiveness. From this, it was rational that effective leadership in an organization is

\footnotetext{
51Yasin, Kepemimpinan Manajer (Eksistensinya Dalam Perilaku Organisasi) (Jakarta: CV Rajawali Press, 2001).

52 Muhammad Zuhdi, 'Challenging Moderate Muslims: Indonesia's Muslim Schools in the Midst of Religious Conservatism', Religions 9, no. 10 (October 2018): 310, https://doi.org/10.3390/rel9100310.

53B M Faturahman, 'Kepemimpinan Dalam Budaya Organisasi', MADANI Jurnal Politik Dan Sosial Kemasyarakatan 10, no. 1 (2018): 1-11.

${ }^{54}$ Faturahman.
} 


\section{Siti Aisyah et al}

strongly influenced by leaders' values, beliefs, and attitudes manifested in organizational life in the broadest sense..$^{55}$

This applies to the organizational culture in pesantren, which makes Kiai an example of a corporate leader who applies leadership to the job. This becomes a form of a motivator that is needed in leadership so that the vision, mission, and goals of Pesantren can be realized. This is an incredible impact to meet the objectives of pesantren, which from observations of researchers conducted on the development of pesantren organizational culture considers that they (subordinates/administrators and teacher board) are partners that must be adequately advanced. Therefore, in the development of corporate culture, it is expected that the values and beliefs of a leader in the members of the organization are powered, the dissemination of values and ideas, and the intensity of the implementation of core values to be inherited and developed by members and leaders of the future. ${ }^{56}$

Organizational culture has meaning as a form of pilot and reflection of the personality of superiors or previous people. Kiai plays a role more, not just a teacher. Kiai acts as a spiritual guide to those who obey and advise in all forms of their life problems, namely the santri, leading crucial rituals and reciting prayers in every critical event and program. The policies of the Kiai in each boarding school become very closely related to the vision, mission, objectives in pesantren education, long-term programs, medium-term events, matters related to using the political, economic, social, cultural, correlation of pesantren huts with other boarding schools, correlation of boarding schools with other educational forums in the country as well as abroad, correlation of boarding schools with the government, correlation of boarding schools using the community as well as others.

In the context of organizational development, proving that cultural meaning in organizational life is considered highly relevant. This is because organizational culture can be regarded as an asset or something very worthy to be appreciated. At least an organizational culture acts as a tool for internal integration. If this gait can function well and is accompanied by a strategist who is considered appropriate, it

55 Mulyadi, Kepemimpinan Kepala Madrasah (Jakarta: Badan Litbang dan Diklat Kementrian Agama RI, 2010).

56 Mamlu'ah, 'Pengembangan Budaya Organisasi Pesantren Dalam Manajemen Pendidikan Islam'. 


\section{Tafkir: Interdisciplinary Journal of Islamic Education}

will be essential to increase organizational performance. Organizational culture has three levels: (1) artifact, covering everything that can be reviewed, heard, and felt, such as the work environment, attitudes, dress, rituals, and celebrations, documents, and technology, (2) exposed values, is a trusted thing in the organization, for example, open communication carried out by the organizational community, (3) basic assumptions, for example, the belief that customers must be treated appropriately and well..$^{58}$

There are several forms and schemes of boarding school culture that run because of encouragement and manifestation of the charisma of a leader in a boarding school or referred to as a Kiai, for example, the tradition of listening to yellow books, haul traditions, practices of asking for the blessings of Kiai prayers and so on. The santri and citizens are obedient to the traditional values built by the Kiai. Kiai means a respected status using a set of efforts on the people. The important Kiai's role is his contribution to how Kiai as a leader, primary element, and central figure of pesantren make efforts to maintain the survival of the pesantren he leads and strengthens the culture or tradition of pesantren that has lived for centuries in the current nature so that the convention does not become extinct. In this case, the success or unification of each component depends on the perception of the individual where the process is handled and where the culture will be moved. Communication and the process of change that is so transparent is crucial because it will choose the perception not how a leader will be perceived, but who will be considered a leader.

\section{CONCLUSION}

Islamic Boarding School is the oldest Islamic educational institution in Indonesia. The leadership position is very strategic in Islam. A good leader will realize a society based on Baldatun Thoyyibatun Wa Rabbun Ghafûr. Leadership in boarding schools has several styles: transformational, charismatic, servant, spiritual, and authentic. A Kiai leads the administration in the boarding school. The leadership style of a Kiai tends to use a charismatic style with authority that is accompanied by

\footnotetext{
${ }^{58}$ Tika Evi, 'Manfaat Bimbingan Dan KOnseling Bagi Siswa SD', Jurnal Pendidikan Dan Konseling 1, no. 2 (2020).
}

53| Vol. 3, No.1, January 2022 


\section{Siti Aisyah et al}

high responsibility. As the leader of the pesantren hut, Kiai has an essential role in shaping organizational culture in pesantren.

The culture of organization and leadership influence each other. Organizational culture influences leadership, and leadership influences corporate culture. Organizational culture and leadership influence job satisfaction and personnel commitment. The leader and founder of the boarding school also has an essential role in shaping the organizational culture in pesantren, which aims to build a character that can distinguish it from other institutions. Thus, Kiai's job as a pesantren leader is to form a personnel commitment to pesantren as an Islamic educational institution. Kiai's essential role is his contribution to how Kiai as a leader, primary element, and central figure of pesantren make efforts to maintain the survival of the pesantren he leads and strengthens the culture or culture of pesantren that has lived for centuries in the current nature so that the tradition does not become extinct.

\section{REFERENCES}

Abu Bakar, H.M. Yunus. ‘Konsep Pemikiran Pendidikan K.H. Imam Zarkasyi Dan Implementasinya Pada Pondok Pesantren Alumni'. UIN Sunan Kalijaga, 2007. Ah. Choiron. 'Budaya Organisasi Pesantren Dalam Membentuk Santri Putri Yang Peduli Konservasi Lingkungan'. Jurnal Palastren 10, no. 2 (2017).

Anwar, Kasful. 'Kepemimpinan Kiai Pesantren: Studi Terhadap Pondok Pesantren Di Kota Jambi'. Kontekstualita: Jurnal Penelitian Sosial Keagamaan 25, no. 2 (2010). Ariandy, ELKA DESTY. 'Pondok Pesantren Di Yogyakrta Yang Didasarkan Pada Kaidah Islam Mengenai Kemasyarakatan'. UAJY, 2009.

Arifin, Imron, Juharyanto, Mustiningsih, and Ahmad Taufiq. 'Islamic Crash Course as a Leadership Strategy of School Principals in Strengthening School Organizational Culture'. SAGE Open 8, no. 3 (1 July 2018): 2158244018799849. https://doi.org/10.1177/2158244018799849.

Arifin, Zainal. 'Authority of Spiritual Leadership at Pesantren Temboro Based on Jamaah Tabligh Ideology'. Jurnal Pendidikan Islam 6, no. 2 (27 December 2017): 265-92. https:// doi.org/10.14421/jpi.2017.62.265-292. 
Tafkir: Interdisciplinary Journal of Islamic Education

A'yuni, Siti Qurrotul, and Radia Hijrawan. 'Analisis Kritis Kepemimpinan Pendidikan Islam Berdasarkan Syarat Dan Ciri-Ciri Kepemimpinan Yang Ideal'. Al-Fahmi: Jurnal Manajemen Pendidikan Islam 2, no. 2 (2020).

Evi, Tika. 'Manfaat Bimbingan Dan KOnseling Bagi Siswa SD'. Jurnal Pendidikan Dan Konseling 1, no. 2 (2020).

Faturahman, B M. 'Kepemimpinan Dalam Budaya Organisasi'. MADANI Jurnal Politik Dan Sosial Kemasyarakatan 10, no. 1 (2018): 1-11.

Fithriah, Nor. 'Kepemimpinan Pendidikan Pesantren (Studi Kewibawaan Pada Pondok Pesantren Salafiyah, Modern, Dan Kombinasi)'. Al Qalam: Jurnal Ilmiah Keagamaan Dan Kemasyarakatan, 2018, 13-30.

Fogg, Kevin W. 'Reinforcing Charisma in the Bureaucratisation of Indonesian Islamic Organisations'. Journal of Current Southeast Asian Affairs 37, no. 1 (1 April 2018): 117-40. https:/ / doi.org/10.1177/186810341803700105.

Hamdi, Saipul, Paul J. Carnegie, and Bianca J. Smith. 'The Recovery of a Non-Violent Identity for an Islamist Pesantren in an Age of Terror'. Australian Journal of International Affairs 69, no. 6 (2 November 2015): 692-710. https://doi.org/10.1080/10357718.2015.1058339.

Hamzah, Siti Raba'ah, Azimi Hamzah, Jamilah Othman, and Sharmila Devi. 'Impact of Islamic Values on the Leadership Style of Muslim Women Academics in Malaysia'. Advances in Developing Human Resources 18, no. 2 (1 May 2016): 187203. https:// doi.org/10.1177/1523422316641402.

Hanafi, Yusuf, Ahmad Taufiq, Muhammad Saefi, M. Alifudin Ikhsan, Tsania Nur Diyana, Titis Thoriquttyas, and Faris Khoirul Anam. 'The New Identity of Indonesian Islamic Boarding Schools in the "New Normal": The Education Leadership Response to COVID-19'. Heliyon 7, no. 3 (1 March 2021): e06549. https://doi.org/10.1016/j.heliyon.2021.e06549.

Herman, Herman. 'Sejarah Pesantren Di Indonesia'. Al-TA’DIB: Jurnal Kajian Ilmu Kependidikan 6, no. 2 (2013): 145-58.

Hosaini, A. 'Kepemimpinan Dan Budaya Organisasi Di Pesantren'. Likhitaprajna 17, no. 2 (2015): 86-95.

Hossain, Manjurul. 'Political Activities of Sheikh Mujibur Rahman as A Charismatic Leader'. London Journal of Research in Humanities and Social Sciences, 22 August 


\section{Siti Aisyah et al}

2019.

https://research.journalspress.com/index.php/socialscience/article/view/ 463.

Idris, Jamaluddin. Manajerial Dan Manajemen. Bandung: Citapustaka Media Perintis, 2013.

Ifendi, Mahfud. 'Pesantren Dan Kepemimpinan Kiai: Studi Kasus Di Pondok Pesantren Mambaus Sholihin Gresik (1980-2020)'. Mudir: Jurnal Manajemen Pendidikan 2, no. 2 (2020): 13-30.

Indrawati, Nur Khusniyah. 'Management by Inspiration: Implementation of Transformational Leadership on Business at Pondok Pesantren*) Sunan Drajat'. Procedia - Social and Behavioral Sciences, The 5th Indonesia International Conference on Innovation, Entrepreneurship, and Small Business (IICIES 2013), $\quad 115 \quad(21 \quad$ February 2014): https://doi.org/10.1016/j.sbspro.2014.02.417.

Javed, Sarfaraz, Azam Malik, and Mutaz Minwer Hala Alharbi. 'The Relevance of Leadership Styles and Islamic Work Ethics in Managerial Effectiveness'. PSU Research Review 4, no. 3 (1 January 2020): 189-207. https://doi.org/10.1108/PRR-03-2019-0007.

Kotzé, Martina, and Petrus Nel. 'Personal Factor Effects on Authentic Leadership'. Journal of Psychology in Africa 27, no. 1 (27 February 2017): 47-53. https://doi.org/10.1080/14330237.2016.1268291.

Liu, Wenbin, and Bernard Gumah. 'Leadership Style and Self-Efficacy: The Influences of Feedback'. Journal of Psychology in Africa 30, no. 4 (3 August 2020): 289-94. https://doi.org/10.1080/14330237.2020.1777033.

Makki, M. 'Model Kepemimpinan Tuan Guru Di Pondok Pesantren Kabupaten Lombok Timur NTB'. Jurnal Manajemen Dan Budaya 1, no. 2 (2021): 65-84.

Mamlu'ah, Aya. 'Pengembangan Budaya Organisasi Pesantren Dalam Manajemen Pendidikan Islam'. Al Ulya : Jurnal Pendidikan Islam 2, no. 1 (22 February 2017): 28-40. https:/ / doi.org/10.36840/ ulya.v2i1.71.

Mardiyah. Keoemimpinan Kyai Dalam Memelihara Budaya Organisasi. Malang: Aditya Media Publishing, 2012. 
Tafkir: Interdisciplinary Journal of Islamic Education

Mastuhu. Dinamika Sistem Pendidikan Pesantren Suatu Kajian Tentang Unsur Dan Nilai Sistem Pendidikan Pesantren. Jakarta: INIS, 1994.

Muali, Chusnul, Moh Rofiki, Hasan Baharun, Zamroni Zamroni, and Lukman Sholeh. 'The Role of Sufistic-Based Kiai Leadership in Developing the Character of Santri in the Pesantren'. AL-ISHLAH: Jurnal Pendidikan 13, no. 3 (2 November 2021): 1705-14. https:// doi.org/10.35445/alishlah.v13i3.1012.

Mubarok, Dede Husni, and Malik Fatoni. 'Mempertahankan Budaya Organisasi Melalui Best Practices Pendidikan Spiritual Leadership Pada Pondok Pesantren'. Jurnal Geneologi: Jurnal Pendidikan Agama Islam 5, no. 1 (2018).

Mulyadi. Kepemimpinan Kepala Madrasah. Jakarta: Badan Litbang dan Diklat Kementrian Agama RI, 2010.

Munaya Ulil Ilmi. ‘Penerapan Disiplin Melalui Budaya Sekolah Pada Siswa Kelas IX MTs Ponpes Islam Al Iman Muntilan'. Instructional Development Journal 3, no. 3 (2020): 203-11.

Najih, Muhammad. 'Sosialisasi Budaya Organisasi Di Pondok Pesantren Muhammadiyyah: Studi Kasus Sosialisasi Budaya Organisasi Di Pendidikan Ulama Tarjih Muhammadiyah'. Jurnal Channel 3, no. 2 (2015).

Noor, Muslichan. 'Gaya Kepemimpinan Kyai'. Jurnal Kependidikan 7, no. 1 (31 May 2019): 141-56. https:/ / doi.org/10.24090/jk.v7i1.2958.

Nurcholish, Madjid. Bilik-Bilik Pesantren Sebuah Potret Perjalanan. Jakarta: Paramadina, 1997.

Nurish, Amanah. 'Women's Same-Sex Relations in Indonesian Pesantren'. Gender, Technology and Development 14, no. 2 (1 January 2010): 267-77. https://doi.org/10.1177/097185241001400207.

Pribadi, Yanwar. 'The Klebun, the Kiai and the Blater: Notes from Western Madura, Indonesia'. South East Asia Research 23, no. 3 (1 September 2015): 303-17. https://doi.org/10.5367/sear.2015.0267.

Qori, HILA. 'Kepemimpinan Karismatik versus Kepemimpinan Transformasional'. Jurnal Analisa 1, no. 2 (2013): 70-77.

Rahmaniah, Aniek. 'Pengembangan Pembelajaran Ilmu Pengetahuan Sosial Pada Pendidikan Dasar'. Madrasah 5, no. 1 (2012): 103-22. 


\section{Siti Aisyah et al}

Raihani. 'Report on Multicultural Education in Pesantren'. Compare: A Journal of Comparative and International Education 42, no. 4 (1 July 2012): 585-605. https:/ / doi.org/10.1080/03057925.2012.672255.

Rokhlinasari, Sri. 'Budaya Organisasi Pesantren Dalam Pengembangan Wirausaha Santri Di Wirausaha Lan Taburo Kota Cirebon'. Jurnal Holistik 15, no. 2 (2014).

Siregar, Fitri Rayani. 'Nilai-Nilai Sekolah Dalam Pembinaan Aktivasi Keagamaan Siswa SD IT Bunayya Padangsidimpuan'. Jurnal Pusat Gender Dan Anak1, no. 1 (2017).

Siswanto, Bedjo. Pengantar Manajemen. Bumi Aksara, 2021.

Soemartono, Triyuni. 'Reconstruction of Education Policy in Jembrana Bali, Best Practices of Creative and Innovative Leadership Using Soft Systems Methodology Based Action Research'. Procedia - Social and Behavioral Sciences, The 5th Indonesia International Conference on Innovation, Entrepreneurship, and Small Business (IICIES 2013), 115 (21 February 2014): 269-82. https://doi.org/10.1016/j.sbspro.2014.02.435.

Solikin, Asep, H.M Fatchurahman, and Supardi. 'Pemimpin Yang Melayani Dalam Membangun Bangsa Yang Mandiri'. Anterior Jurnal 16, no. 2 (2017): 90-103.

Spoelstra, Sverre. 'The Paradigm of the Charismatic Leader'. Leadership 15, no. 6 (1 December 2019): 744-49. https://doi.org/10.1177/1742715019853946.

Syafe'i, Imam. 'Pondok Pesantren: Lembaga Pendidikan Pembentukan Karakter' . AlTadzkiyyah: Jurnal Pendidikan Islam 8, no. 1 (2017): 61-82.

Thaib, Muhammad Ichsan. 'Kepemimpinan Pendidikan Dalam Islam'. Jurnal Intelektualita 4, no. 66-95 (2016).

Usman, Jarjani, Syabuddin Syabuddin, and Faishal Zakaria. 'Teungku Identity Development: The Role of Dayah Community of Practice'. SAGE Open 11, no. $3 \quad(1 \quad$ July 2021$): \quad 21582440211031532$. https://doi.org/10.1177/21582440211031532.

Wekke, Ismail Suardi, and Sanusi Hamid. 'Technology on Language Teaching and Learning: A Research on Indonesian Pesantren'. Procedia - Social and Behavioral Sciences, 2nd World Conference on Educational Technology Research, 83 (4 July 2013): 585-89. https:// doi.org/10.1016/j.sbspro.2013.06.111. 


\section{Tafkir: Interdisciplinary Journal of Islamic Education}

Yakubu, Abubakar. 'Pondok, Tsangaya, and Old Age Spiritual Wellbeing'. Tafkir: Interdisciplinary Journal of Islamic Education 2, no. 2 (25 July 2021): 122-38. https://doi.org/10.31538/tijie.v2i2.44.

Yasin. Kepemimpinan Manajer (Eksistensinya Dalam Perilaku Organisasi). Jakarta: CV Rajawali Press, 2001.

Zuhdi, Muhammad. 'Challenging Moderate Muslims: Indonesia's Muslim Schools in the Midst of Religious Conservatism'. Religions 9, no. 10 (October 2018): 310. https://doi.org/10.3390/re19100310. 